\title{
The distribution of injected plasmid DNA throughout the organs and the expression of human apoA-1 gene in vivo
}

\author{
S.M. Novikova ${ }^{1}$, V.A. Kordium \\ The Institute of Molecular Biology and Genetics, NAS of Ukraine \\ 150, Academician Zabolotny Str., Kyiv, 03143, Ukraine \\ ${ }^{1}$ Institute of Gerontology of AMS of Ukraine \\ 67, Vyzhgorodska Str., Kyiv, 04114, Ukraine
}

I.M. Gilchuk, D.M. Irodov, P.L. Starokadomskyy, I.M. Pishel', O.K. Toporova,

jukozel@yahoo.com

\begin{abstract}
The elaboration of methods of gene delivery into somatic cells is the foundation of gene therapy development. There is necessity to develop new and more effective vectors as well as corresponding methods of gene delivery into the target tissues. The analysis of distribution of vector molecules in tissues and transgene expression are the constituent parts of evaluation of effectiveness of gene therapy methods for a target gene delivery. The study on the transfer of the plasmid DNA, containing human apoA-1 gene, in complex with polyetilenimine (PEI) into rat and rabbit liver parenchyma has been performed. The expression of human apoA-1 gene in vivo has been examined.
\end{abstract}

Keywords: apolipoprotein A-1, polyetilenimine, transgene expression, transgene distribution.

Introduction. Hypercholesterolemia is considered to be one of the factors contributing the development of both atherosclerosis (AS) and ischemic heart disease due to the increased cholesterol content in blood plasma or serum. Reverse transportation of cholesterol (from vascular bed to liver) takes place in high-density lipoproteins (HDL), the basic protein of which is apolipoprotein A-1 (apoA-1). The investigation carried out on transgenic and knockout mice [1], and transgenic rabbits [2] confirmed the protective (anti-atherogenic) role of apoA-1 on the development of experimentally

(C)I.M. GILCHUK, D.M. IRODOV, P.L. STAROKADOMSKYY, I.M. PISHEL, O.K. TOPOROVA, S.M. NOVIKOVA, V.A. KORDIUM, 2006 induced atherosclerotic damages of aorta. Developing the approaches to gene therapy of AS, a series of successful experiments in transporting apoA-1 gene as a part of recombinant adenoviral expression vectors in mice cells in vivo has been performed [3-5]. Nevertheless, due to the significant disadvantage of adenoviral vectors (i.e. immune response of the organism to the introduction of viral vector) the development of non-viral means for delivering target DNA is still in progress. Non-viral methods of delivery are based on cation carriers of DNA and are less effective comparing to viral vectors, however, they allow multiple introductions and do not have some specifically viral disadvantages [6]. 
The important task in developing the approaches to gene therapeutic corrections in some diseases is to analyse the effectiveness of gene transporting, to study the distribution of vector molecules in tissues as well as expression of transgene in vivo. The goal of this work was to study the transportation of human apoA-1 containing plasmid DNA, as a part of complexes of DNA/polyethyleneimine (PEI) in liver parenchyma of rats and rabbits and to investigate the distribution of target gene in animal organisms, and to study apoA-1 expression in vivo.

Materials and Methods. Plasmid pTRapo [7] and

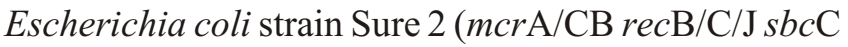
umuC $u v r \mathrm{C}$ hsdSMR) ("Stratagene", USA) was used. Plasmid DNA was isolated according to the method described in [8]. Total DNA of cells was obtained using Genomic DNA Purification kit ("Fermentas", Lithuania).

ICR mice (27-28 g, 2.5-month old), Wistar rats $(150-200 \mathrm{~g})$ and rabbits of Chinchilla breed (2500-3000 kg), and SPEV cell line (swine embryonic kidney cells), obtained from Russian Collection of Cell Cultures (Saint Petersburg) were used in the research.

Introduction of plasmid DNA. Plasmid DNA and PEI complexes (branched, $25 \mathrm{kDa}$, "Aldrich", USA) (DNA/PEI) in mass equivalent 1:2 were prepared in accordance to the method described in [8]. DNA/PEI preparation was injected in liver parenchyma - 100 and $240 \mathrm{mg}$ of DNA to rats and rabbits respectively. All procedures with animals were carried out according to commonly accepted rules of treating animals and applying anaesthesia.

PCR analysis. The following primers have been used:

Ap-f: 5'-TGAAAGCTGCGGTGCTGACCTTGG-3'; Ap-r: 5' -ATCTCCTCCTGCCACTTCTTCTGG-3' ; Ap(n)-f: 5' -CGAGTGAAGGACCTG-3' ; Ap(n)-r: 5' -GGCTGCACCTTGGC-3' ; Ap(h-Rab)-f: 5' -TCTTCTCCCGCTCTGTG-3' ; Ap(h-Rab)-r: 5' -GCAGAGGAGGTGGTGAA-3' ; Ap(h-PigRab)-f: 5' -TCACCTGGCTGCAATGA-3' ; Ap(h-PigRab)-r: 5' -TCCTTTGCAGGGGACAT-3' .

Primer sequences were calculated using Vector NTI software. Primers were synthesised by "Sintol" Company (Russia).
Taq-polymerase ("Amplisense", Russia) was used to perform PCR. Total volume of the reaction mixture was $25 \mathrm{mkl}$. For second stage of PCR $5 \mathrm{mkl}$ of the reaction mixture were taken. PCR was performed using Biometra Personal Cycler equipment (USA). Products of amplification were separated with electrophoresis in $1.0 \%$ agarose gel and visualised using ethidium bromide.

RT-PCR analysis. Animal cells DNA/RNA were isolated from tissues and blood using Ribosol A reagent kit ("Amplisense") in accordance to the manufacturer's recommendations. Sample DNAs were hydrolyzed using deoxyribonuclease I ("Sigma", USA). cDNA was synthesised using "Reverta L-100" reagent kit ("Amplisense"). RT-PCR was performed using the pair of primers Ap-f/Ap-r as described later on. Amplification products were separated by electrophoresis in $1.5 \%$ agarose gel.

Western Blotting analysis. Prior to protein introduction urine was added to gel samples to the concentration of $4 \mathrm{M}$. Electrophoresis of proteins was performed in $12 \%$ polyacrylamide gel with sodium dodecyl sulphate. With the purpose of immunedetection of the proteins, they were moved onto PVDF membrane ("Amersham Biosciences", Sweden). Unoccupied places on the membrane were blocked with 3\% skim milk. Membrane was incubated for 1 hour with monoclonal antibodies against human apoA-1. At the next stage, blot was incubated for 1 hour with antibodies against rabbit $G$ immunoglobulines conjugated with horse radish peroxidase (P-RAM 1/1000, "IMTEK", Russia).

Immune complexes were visualised using the method of enhanced chemoluminescence (ECL), luminol ("Sigma") was used as substrate [8]. To register ECL X-ray film Retina XBM ("Lizophorm", Ukraine) was used. The captures obtained were scanned and the quantitative assessment of signal intensity was conducted using Total Lab software ("Amersham Biosciences"). Human ApoA-1 protein ("Sigma") was chosen to be the standard of molecular weight and concentration.

Results and Discussion. Distribution analysis of plasmid DNA in the organism. To investigate the presence of transgene in animal cell DNAs, the methods of Southern Blotting analysis, as well as 


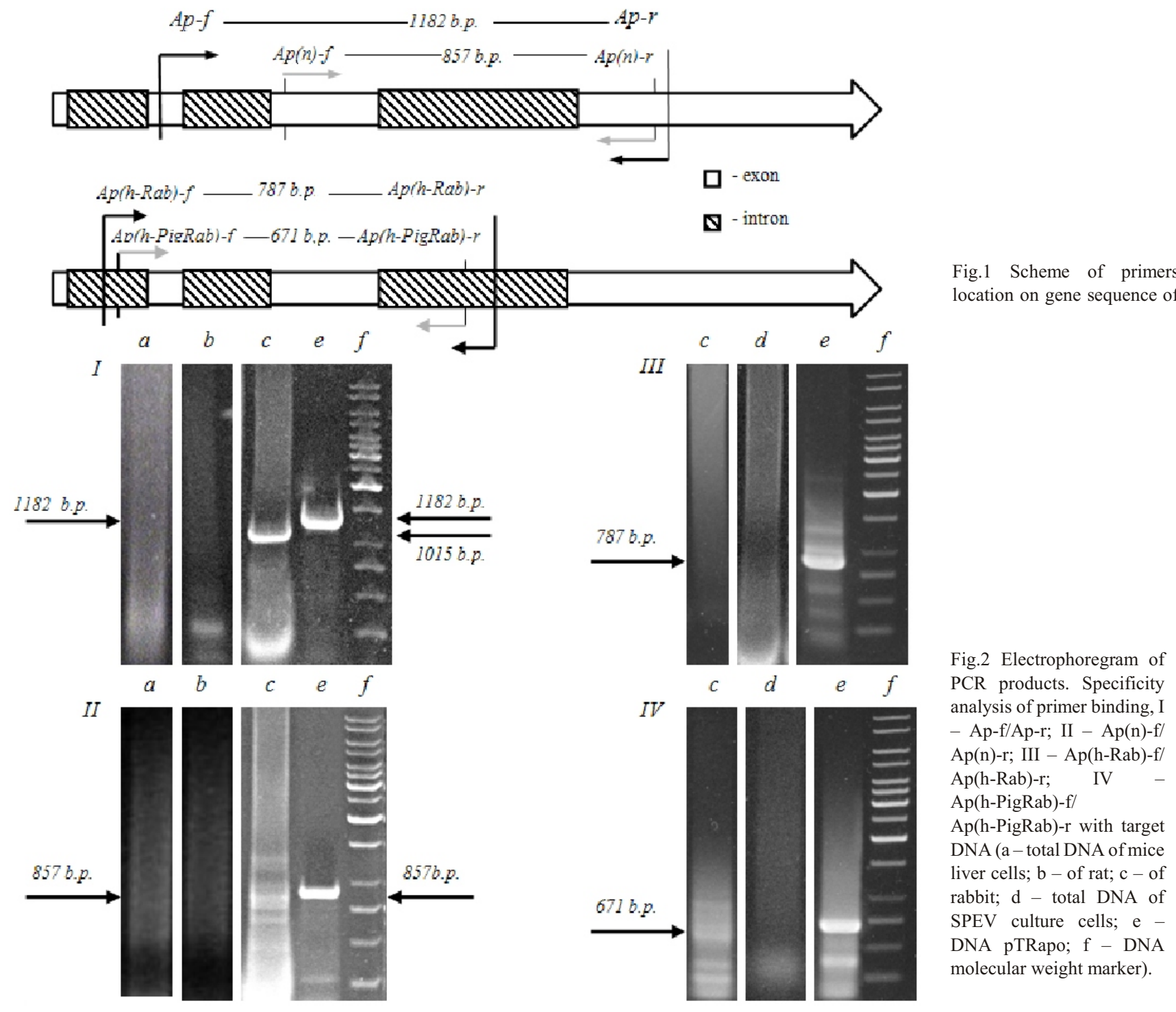

various kinds of PCR have been used. Owing to its high sensitivity, PCR allows detecting target sequences in the minimal quantity, and besides, this method is simple to use. Current work presents human apoA-1 gene being detected in vivo using different species-specific primers.

The primers were designed according to homology of known DNA sequences of human apoA-1 gene (Gene Bank Accession No.AY422952), mouse (Gene Bank Accession No.U79572), rat (Gene Bank Accession No.J02597), rabbit (Gene Bank Accession No.X06659), and swine (Gene Bank Accession No.L00626). To analyse the target gene in the presence of mice and rat DNAs, two pairs of primers Ap-f/Ap-r and $A p(n)-f / A p(n)-r$, which are specific to $2 n d, 4$ th and 3 rd, 4th exons of human apoA-1 gene, respectively, were estimated [9]. To analyse the presence of transgene in the presence of rabbit and swine DNA due to high homology of exon sequences of human gene and the genes of these animals (the use of Ap- $\mathrm{f} / \mathrm{Ap}-\mathrm{r}$ primers on apoA-1 of rabbit results in synthesis of 1015 b.p. long amplicon), two extra pairs of primers have been used Ap(h-Rab)-f/Ap(h-Rab)-r and Ap(h-PigRab)-f/Ap(h-PigRab)-r (Fig.1) specific to introns 1 and 3 [9].

To investigate the specificity of primers, plasmid DNA containing human apoA-1 gene, total DNA, isolated from liver tissues of mouse, rat, rabbit and 

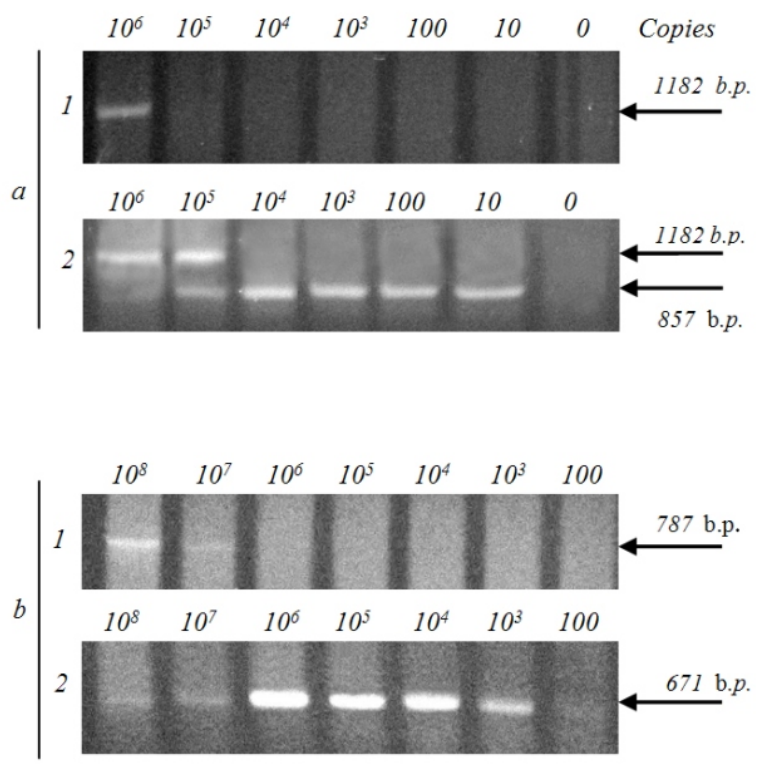

Fig.3 Electrophoregram of PCR products. Sensitivity analysis of "nested" PCR with pairs of primers, a - Ap-f/ Ap-r and Ap(n)-f/ Ap(n)-r; b Ap(h-Rab)-f/ Ap(h-Rab)-r and Ap(h-PigRab)-f/ Ap(h-PigRab)-r (1 - first

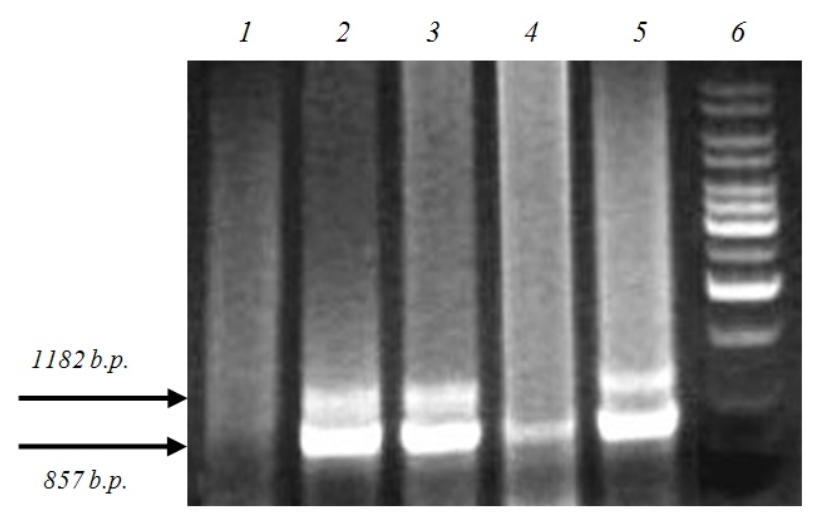

Fig.4 Electrophoregram of PCR analysis for the presence of transgene in total DNA in rat liver cells using PCR: 1 - animal without DNA/PEI injection, 2-5 - animals with injections of DNA/PEI complexes; 6 - DNA molecular weight marker

SPEV culture cells, was used. All pairs of primers were shown to be specific to human apoA-1 gene and aspecific to the corresponding animal gene (Fig.2).

To detect transgene in tissues, we used double-stage ("nested") PCR, which allows increasing sensitivity significantly, and the use of the internal pair of primers, in its turn, provides high analysing specificity.
"Nested" PCR was carried out in two variants using the following sets of primers:

1)Ap-f/Ap-r - external pair of primers, $\operatorname{Ap}(n)-f / A p(n)-r$ - internal pair of primers;

2) Ap(h-Rab)-f/Ap(h-Rab)-r - external pair of primers, Ap(h-PigRab)-f/Ap(h-PigRab)-r - internal pair of primers.

The following conditions (temperature and duration) were determined to be optimal for Ap-f/Ap-r pair: denaturation $-94^{\circ} \mathrm{C}, 20 \mathrm{sec}$; hybridisation with matrix $-62^{\circ} \mathrm{C}, 30 \mathrm{sec}$; elongation $-72^{\circ} \mathrm{C}, 30 \mathrm{sec}, 30$ cycles; for $\mathrm{Ap}(\mathrm{n})-\mathrm{f} / \mathrm{Ap}(\mathrm{n})-\mathrm{r}$ : denaturation $-94^{\circ} \mathrm{C}, 20$ sec; hybridisation with matrix $-50^{\circ} \mathrm{C}, 30 \mathrm{sec}$; elongation $-72^{\circ} \mathrm{C}, \quad 30 \mathrm{sec}, 30$ cycles; for $\mathrm{Ap}(\mathrm{h}-\mathrm{Rab})-\mathrm{f} / \mathrm{Ap}(\mathrm{h}-\mathrm{Rab})-\mathrm{r}$ : denaturation $-94^{\circ} \mathrm{C}, 20 \mathrm{sec}$; hybridisation with matrix $-46^{\circ} \mathrm{C}, 30 \mathrm{sec}$; elongation $72^{\circ} \mathrm{C}, \quad 30 \quad \mathrm{sec}, \quad 30$ cycles; for Ap(h-PigRab)-f/Ap(h-PigRab)-r: denaturation $-94^{\circ} \mathrm{C}$, $20 \mathrm{sec}$; hybridisation with matrix $-48^{\circ} \mathrm{C}, 30 \mathrm{sec}$; elongation $-72^{\circ} \mathrm{C}, 30 \mathrm{sec}, 30$ cycles.

To determine PCR sensitivity, the matrix containing $500 \mathrm{ng}$ of animal total DNA with different amounts of pTRapo plasmid has been used. At the mentioned above conditions, PCR sensitivity for Ap-f/Ap-r primers was $\sim 10$ ng of plasmid DNA, which corresponds to $\sim 10^{6}$ of the copies of target gene per reaction. That was after $A p(n)-f / A p(n)-r$ application during the second stage of reaction the sensitivity of PCR was much higher, which corresponded $\sim 10$ gene copies per reaction. For two other pairs of primers, sensitivity of the method was determined: first stage of reaction with $A p(h-R a b)-f / A p(h-R A b)-r$ amounted to $\sim 10^{7}$ copies, "nested" PCR (second stage with primers Ap(h-PigRab)-f/Ap(h-PigRab)-r) amounted to $\sim 10^{6}$ copies (Fig.3). It is noteworthy that total DNA was usually obtained from $\sim 25 \mathrm{mg}$ of freeze-dried liver tissue, which corresponds to 107 of cells [10], the output of total DNA was $\sim 12.5 \mathrm{mkg}$. Therefore, we have optimised PCR for detection of human apoA-1 gene in total DNA of mice, rats, rabbit, and swine.

PCR with the purpose of detecting human apoA-1 gene in tissues of rats and rabbits using the selected pairs of primers has been performed. Total DNA of rat liver cells was analysed on the 6th day after pTRapo plasmid introduction. The analysis revealed the presence of transgene (Fig.4), which testifies in favour 

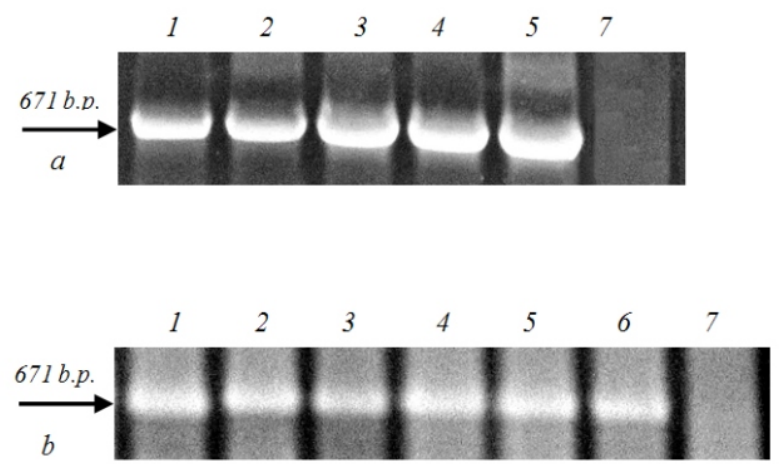

Fig. 5 Electrophoregram of distribution analysis of plasmid DNA in organs of rabbits using PCR analysis: 1 - lymph node; 2 - liver; 3 - lungs, 4 - heart; 5 - kidneys; 6 - aorta walls; 7 - liver of rabbit without DNA/PEI injection (a - on the 6th day, $\mathrm{b}$ - on the 85th day after DNA/PEI complexes injection). The Fig. presents the results of three independent investigations.

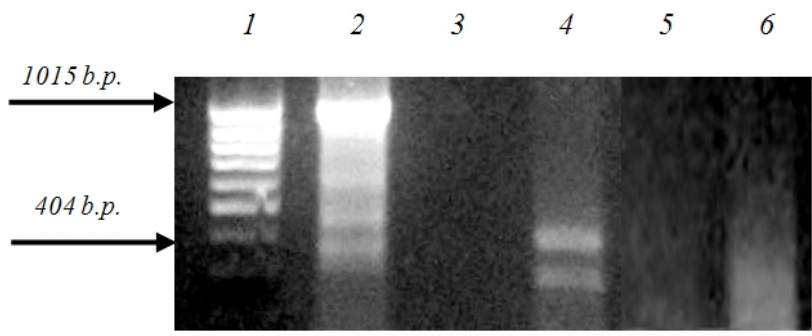

Fig.6 Electrophoregram of mRNA presence of human apoA-1 using RT-PCR method: 1 - DNA molecular weight marker, 2-4 - rabbit liver samples with DNA/PEI injection; 5, 6 - rabbit liver samples without DNA/PEI injection; 2 - PCR of DNA/RNA sample, obtained from rabbit liver cells (analysis of RNA isolation effectiveness); 3, 5 - PCR of DNAase-treated DNA/RNA sample without RT reaction (analysis of DNAase treatment effectiveness); 4-6 - PCR of DNAase treated DNA/RNA sample after RT reaction (analysis of specific mRNA presence). The Fig. presents the results of three independent investigations.

of effective plasmid DNA delivery by injection in vivo as a part of PEI/DNA complexes. The presence of human apoA-1 gene was revealed (Fig.5) on the 6th and 85 th day after introducing genetic material, in almost all organs of experimental animals (rabbits), the tissues of which had to be analysed (liver, heart, lungs, kidneys, lymph nodes). The result obtained may testify in favour of indirect DNA transfer and may be explained by the fact that the part of liver-introduced plasmid DNA gets into the blood stream with intercellular liquid and lymph or with venous blood through capillaries, and is spread in organism. In our case it is hard to determine whether plasmid DNA gets into the tissues of other organs (heart, lungs, kidneys, lymph nodes) or whether only plasmid, located in blood capillaries, is detected. Nevertheless, literature data indicate that intravenously introduced PEI/DNA complexes are capable of reaching and have the capacity of providing expression of marker genes in cells of heart, spleen, liver, kidneys, and to the highest extent - in bronchial and lung vessels endothelial cells [11]. The presence of target DNA in liver tissues of rabbits has been observed for not less than 85 days after introduction.

Expression analysis of apoA-1 in vivo. Pairs of primers Ap-f/Ap-r and Ap(n)-f/Ap(n)-r, specific to human apoA-1 gene exons, may be used in RT-PCR to analyse transgene expression not only in liver cells of mice and rats but of rabbit as well. It is possible due to the fact that rabbit apoA-1 gene is expressed in intestine cells only $[12,13]$. As a result, specific 404 b.p. long amplicon is synthesised, which is different in size from amplicons formed on matrix of human apoA-1 gene (1182 b.p.) and rabbit (1015 b.p.) with the use of Ap-f/Ap-r primers. RT-PCR analysis of total RNA of rabbit liver cells on the 85 th day after pTRapo introduction revealed the presence of human apoA-1 mRNA (Fig.6).

Two chief methods for apoA-1 protein detection in blood plasma of transgenic or transformed animals are Enzyme-Linked Immune Sorbent Assay (ELISA) and Western Blotting Analysis. Amino acid apoA-1 sequence of animals is highly homologous with human apoA-1 gene [14]. There are two issues that make the analysis more difficult, namely, blood plasma containing animal apoA-1 gene in rather high concentration and molecular weight of apoA-1, which does not differ essentially for different species.

The selection of system of reagents for immune-chemical detection of human apoA-1 protein in blood plasma of rabbits using both ELISA and Western Blotting was the first stage of our work. Monoclonal antibodies against human apoA-1 (3F10, 1:300) ("ICN Biomedicals Inc"., USA) and MGH Laa (1:500, "IMTEK") were tested for binding specificity with human apoA-1 gene in the presence of blood plasma proteins of rabbits, rabbit apoA-1 in particular. Only 3F10 antibodies are applicable for this 


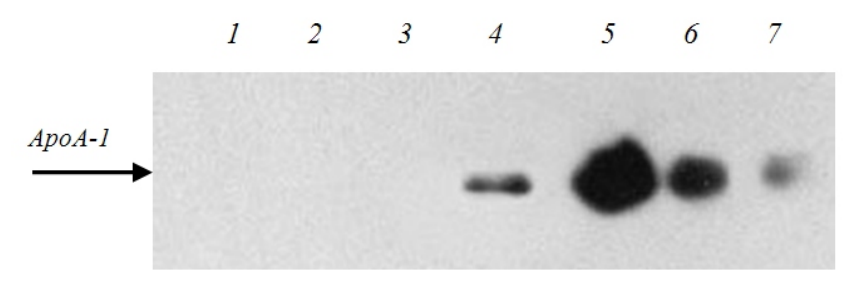

Fig.7 Immune-blot analysis of blood samples of rabbits, injected with DNA/PEI complexes with plasmid: 1-3 - pTR; 5-7 - pTRapo; 4 - human apoA-1 protein ( $\sim 1.7 \mathrm{ng})$. The amount of material applied on the bands 1-3 and 5-7 corresponds to $1.25 \mathrm{Ml}$ of rabbit blood plasma.

investigation, which is carried out correctly using Western Blotting analysis only. It is conditioned by the fact that antibodies used were bound with components of blood plasma of rabbits. Therefore, we have optimised the method of immune-chemical detection for human apoA-1 in blood plasma of rabbits.

Investigating the synthesis of human apoA-1 in vivo the rabbits under investigation were divided into two groups. The first group of rabbits was introduced with human apoA-1 gene as a part of pTRapo vector, the second group (control) was introduced with $p T R$ plasmid containing no target gene. On the 6th day after injection, human apoA-1 protein in blood plasma of first group of rabbits was detected using the method of Western Blotting, while in blood plasma of the second group of rabbits it was not detected (sensitivity of Western Blotting method was $\sim 670 \mathrm{ng}$ of human protein/ml of rabbit blood plasma).

Having performed quantitative assessment of transgene expression, the concentration of human apoA-1 in blood plasma was $1.6-20.2 \mathrm{mkg} / \mathrm{ml}$ from rabbit to rabbit (Fig.7). For comparison - human apoA-1 protein of rabbit in blood plasma of rabbits was in the concentration of $\sim 800 \mathrm{mkg} / \mathrm{ml}$ [2]. This level of expression of transgene may be explained by the specificity of vector or/and insufficient effectiveness of transfection by DNA/PEI complexes in order to achieve the physiological level of protein synthesis, as well as, possible shorter half-lifetime of human apoA-1 comparing to apoA-1 of rabbit in blood of this animal. On the other hand, this approach may turn to be effective in order to investigate therapeutic effect conditioned by the introduction of these complexes with subsequent optimisation of the method used.
Conclusions. Analysis of the target gene presence and mRNA synthesis in tissues of test animals using suggested primers and at the proposed PCR and RT-PCR conditions are adequate in regards of the goal set and may be used to study the transportation, spreading and expression of transgene in vivo.

The results obtained on the presence duration of introduced pTRapo and its distribution in organism present successful transportation of target DNA at DNA/PEI injection in liver parenchyma, preservation of transgene in liver cells of rabbits, and synthesis of mRNA of target gene in the course of at least 85 days after injection. Optimisation of immune-chemical method of detecting human apoA-1 in blood plasma of rabbits has been achieved. The optimised method allows detecting not less than $670 \mathrm{ng}$ of human apoA-1 in $1 \mathrm{ml}$ of plasma.

The results present the expression of human apoA-1 in blood plasma of rabbits introduced with pTRapo.

Ю. Н. Гильчук, Д. М. Иродов, П. Л. Старокадомский, И. Н. Пишель, Е. К. Топорова, С. Н. Новикова, В. А. Кордюм

Распространение по органам введенной плазмидной ДНК и экспрессия гена anoA-1 человека in vivo

Резюме

Разработка способов доставки генов в соматические клетки является фундаментальной основой развития генной терапии. Необходимость создания новых, более эффективных векторов и соответствуюших методов доставки векторов в целевые ткани актуальна и в настоящее время. Анализ распределения векторных молекул в тканях и экспрессия трансгена являются составной частью оиенки эффективности генотерапевтических методов доставки иелевых генов. В данной работе изучен перенос плазмидной ДНК, содержащей ген апоА-1 человека, в составе комплексов с полиэтиленимином в паренхиму печени крыс и кроликов. Исследована экспрессия гена апоА-1 in vivo.

Ключевые слова: аполипопротеин A-1, полиэтиленимин, экспрессия трансгена, распределение трансгена.

REFERENGES:

1.Rubin E. M., Ishida B. Y., Clift S. M., Krauss R. M. Expression of human apoliprotein A-I in transgenic mice results in reduced plasma levels of murine apolipoprotein A-I and the appearance of two new high density lipoprotein size subclasses // Proc. Nat. Acad. Sci. USA.-1991.-88.-P. 434-438.

2.Duverger N., Kruth H., Emmanuel F., Caillaud J.-M., Viglietta C., Castro G., Tailleux A., Fievet C., Fruchart J. C., Houdebine L. M., Denefle $P$. Inhibition of atherosclerosis development in cholesterol-fed human apolipoprotein A-I-transgenic rabbits // Circulation.-1996.-94.-P. 713-717.

3.Belalcazar L. V., Merched A., Carr B., Oka K., Chen K.-H., Pastore L., Beaudet A., Chan L. Long-term stable expression of human apolipoprotein A-I mediated by helper-dependent adenovirus gene transfer inhibits atherosclerosis progression and remodels atherosclerotic plaques in a mouse model of familial 
hypercholesterolemia // Circulation -2003.-107_-P $2726-2732$

4.Linthout S. V., Collen D., De Geest B. Effect of promoters and enhancers on expression, transgene DNA persistence, and hepatotoxicity after adenoviral gene transfer of human apolipoprotein A-I // Hum. Gene Ther.-2002. - 13. - P. 829-840.

5.Benoit P., Emmanual F., Caillaud J. M., Bassinet L., Castro G., Gallix P., Fruchart J. C., Branellec D., Denefle P., Duverger N. Somatic gene transfer of human ApoA-I inhibits atherosclerosis progression in mouse models // Circulation.-1999. - 99.-P. 105-110.

6.Богданенко Е. В., Свиридов Ю. В., Московиев А. А., Жданов Р. И. Невирусный перенос генов in vivo в генной терапии // Вопр. мед. химии.-2000.-46, № 3.-С. 226-246.

7.Топорова Е. К., Новикова С. Н., Лихачева Л. И., Сухорада Е. М., Рубан Т. А., Козел Ю. Н., Иродов Д. М., Кордюм В. А. Невирусная доставка гена anoA-1 человека в клетки млекопитающих in vitro и in vivo // Біополімери і клітина.—2004.-20, № 1-2.-С. $25-32$.

8.Гільчук Ю. М., Сухорада О. М., Рубан Т. А., Топорова Е. К., Кордюм В. А. Вивчення транзиторної експресії гена апоA-1 людини під регуляцією різних гібридних послідовностей у клітинах СНОК1 // Біополімери і клітина.—2006.—22, № 3.-С. $210-217$.
9.Breslow J. L. Apolipoprotein genetic variation and human disease // Physiol. Rev.-1988.-68.-P. 85-132.

10.Гулак П. В., Дудченко А. М., Зайцев В. В., Лукьянова Л. Д., Новиков К. Н., Орлов С. Н., Покудин Н. И., Попова О. А., Уголев А. Т. Гепатоцит: Функционально-метаболические свойства.-М.: Наука, 1985.-270 с.

11.Lungwitz U., Breunig M., Blunk T., Gopferich A. Polyethylenimine-based non-viral gene delivery systems // Eur. J. Pharm. Biopharm.-2005.-60.-P. 247-266.

12.Chao Y., Yamin T., Thompson G. M., Kroon P. A. Tissue-specific expression of genes encoding apolipoprotein $\mathrm{E}$ and $\mathrm{AI}$ in rabbits // J. Biol. Chem.-1984.-259.-P. 5306-5309.

13.Pan T., Hao Q., Yamin T., Dai P., Chen B., Chen S., Kroonand P. A., Chao $Y$. Rabbit apolipoprotein A-I mRNA and gene: evidence that rabbit apolipoprotein A-I is synthesized in the intestine but not in the liver // Eur. J. Biochem.-1987.-170.-P. 99-104.

14.Frank P. G., Marcel Y. L. Apolipoprotein A-1: structure-function relationships // J. Lipid Res.—2000._41.—P. 853-872.

УДК $577.213 .3+577.215+577.217$ 